\title{
Correction to: Potential importance of B cells in aging and aging-associated neurodegenerative diseases
}

\section{Arya Biragyn $^{1} \cdot$ Maria Aliseychik $^{2} \cdot$ Evgeny Rogaev $^{2,3,4}$}

Published online: 14 January 2019

(C) This is a U.S. government work and not under copyright protection in the U.S.; foreign copyright protection may apply 2019

\section{Correction to: Semin Immunopathol https://doi.org/10.1007/s00281-016-0615-8}

The original version of this article unfortunately contained mistakes. Two references were given incorrectly (under number 40 and 41). The correct references are:

40. Miller, AH, Maletic, V, and Raison, C (2009) Inflammation and its discontents: the role of cytokines in the pathophysiology of major depression. Biol Psychiatry 65:732-741

41. Maes, M (1999) Major depression and activation of the inflammatory response system. Adv Exp Med Biol 461:25-46

Publisher's Note Springer Nature remains neutral with regard to jurisdictional claims in published maps and institutional affiliations.

The online version of the original article can be found at https://oi.org/ 10.1007/s00281-016-0615-8

Arya Biragyn

biragyna@mail.nih.gov

1 Immunoregulation Section, National Institute on Aging, 251 Bayview Blvd, Suite 100, Baltimore, MD 21224, USA

2 Brudnick Neuropsychiatric Research Institute, University of Massachusetts Medical School, Worcester, MA, USA

3 Department of Genomics and Human Genetics, Russian Academy of Sciences, Institute of General Genetics, Moscow, Russia

4 Center for Brain Neurobiology and Neurogenetics, Siberian Branch of the Russian Academy of Sciences, Institute of Cytology and Genetics, Novosibirsk, Russia 